TRADUÇÃO

\title{
Plebe, política e acontecimento, de Alain Brossat
}

Tradução e notas: Breno Isaac Benedykt, Mauricio Pelegrini e Renan Ferreira da Silva ${ }^{1}$

\section{Apresentação da tradução}

Breno Isaac Benedykt

Professor de filosofia na Paris VIII, Alain Brossat é autor de uma série de trabalhos - livros, artigos e ensaios -, que condensam uma trajetória intelectual tecida entre rigor filosófico, análise histórica e militância política. O presente artigo, publicado em 2005, ao lado de textos de Fulvia Carnela, Pascal Michon e Philippe Hauser, pela editora L'Harmmattan, numa edição dedicada a homenagear o pensamento de Michel Foucault, falecido vinte anos antes, reflete um momento da vida intelectual de Brossat ligado à compreensão e à incorporação do pensamento do autor de Vigiar e Punir.

Autor do Dictionnaire Foucault, publicado em 2014, pela editora Demopolis, Brossat se dedica, no presente artigo, a extrair do pensamento de Foucault luzes que nos ajudem a pensar nossa atualidade. Focando nos acontecimentos de 11 de setembro de 2001 e seus efeitos políticos, Brossat parece interessado em compreender como e por que Foucault segue sendo, hoje, o autor que nos permite pensar a política aquém e para além do Estado. Para isso, Brossat resgata o modo Foucault de pensar as relações de poder, suas implicações com os saberes jurídicos e as formas de identificação e cisão do social, por meio de diferenciações morais e subjetivações normativas, sem, com isso, deixar de lado o jeito Foucault de pensar e se interessar pelos brilhos "da" plebe; suas resistências, seu acontecimento.

Assim, nos diz Brossat, Foucault teria nos ensinado a dar dois passos decisivos: pensar a política como uma questão desvinculada daquela do Estado; e plebe como acontecimento que desfaz as distribuições e as malhas de relações de poder, que sustentam subjetividades identificadas com a moral de um povo ou, até mesmo, de uma classe operária, num momento de insurgência.

Crítico da esquerda parlamentar francesa e, ainda mais, de teóricos que se posicionam à espera do vindouro dia da revolução, Brossat nos revela uma capacidade ímpar de ler o pensamento de Foucault com precisão, sem deixar de lado a atitude singular de uma crítica radical às tensões políticas do presente.

Mas, afinal, por que Foucault? Talvez seja essa a principal questão deste ensaio de Brossat. De um Brossat que se apropriou, ao seu modo, do pensamento de Foucault, reavivando falas do filósofo, que se encontram em entrevistas, em textos avulsos e em mesas de debate - sua maioria do início da década de 1970 (momento em que Foucault se engaja

\footnotetext{
${ }^{1}$ Breno Isaac Benedykt é doutorando em Filosofia na Universidade de São Paulo (bolsista FAPESP); Maurício Pelegrini é doutorando em História na Unicamp; Renan Ferreira da Silva é doutorando em Filosofia na Universidade de São Paulo.
} 
no G.I.P. e confronta mais diretamente o pensamento de Marx, além de traçar diálogo com Edward P. Thompson) -, para nos mostrar porque "Foucault é um desses raros 'lugares', a partir dos quais é possível se considerar uma renovação ou um resgate da política em tempos de declínio da democracia parlamentarista contemporânea".

Encontrar Foucault, sugere Brossat, em 2005, em uma passagem deste seu ensaio, seja, muito provavelmente, ver suas sugestões em "práticas, gestos, atores e, de um modo mais geral, um novo tom da política radical, que tem em comum a recusa" às relações de poder, cujos dispositivos disciplinares nos reconduzem, todos, às formas institucionalizadas da política. 


\section{Plebe, política e acontecimento}

Alain Brossat

À frente das numerosas incitações que nos chegaram de Foucault, há aprender a desvincular a questão da política daquela do Estado. Exercitar-se a ver a política tomar forma lá onde se abre a brecha de um acontecimento, onde se compõe uma resistência ao intolerável, onde as máquinas do poder se interrompem, onde deslocamentos se produzem, engajando subjetividades e ações que desnudam o vazio da situação anterior. Foucault nos ajudou a compreender, dentre outras coisas, a que ponto a doxa marxista havia acorrentado nossa abordagem da política àquela do Estado - quer esteja em questão sua conquista, sua colonização ou sua destruição. Ele nos encorajou a realizar uma renovação de nosso entendimento político, justamente nos lugares onde era tido como importante se desvincular de uma apreensão da política em nome das condições da dialética histórica, do progressismo e do historicismo, de uma fetichização do significante maior de toda política marxista - o proletariado.

Foucault não nos propôs uma "teoria de renovação" da ação política; ele, simplesmente, nos abriu sua "caixa de ferramentas". E é nela que nós encontramos algumas palavras-chave: plebe, intolerável, resistência, poder, acontecimento. O que nos interessa, com essas palavras, tem duplo viés: por um lado, a possibilidade de considerar uma narrativa da história das sociedades modernas do Ocidente que escapa às restrições da falsa alternativa - história do Estado ou história dos bons fins revolucionários; por outro lado, a possibilidade de uma abordagem da ação política que se desvincule o mais radicalmente possível das condições estabelecidas, pela submissão de toda política às regras da representação, do parlamentarismo e do jogo dos partidos políticos. Foucault é um desses raros "lugares", a partir do qual é possível se considerar uma renovação ou um resgate da política em tempos de declínio da democracia parlamentarista. Nessa perspectiva, a retomada da política não toma a forma da mítica "alternativa", ostentada pelos neomarxistas e pelas nebulosas adjacentes ("altermundialismo", Attac ${ }^{2} \ldots$ ), mas, primordialmente, a de uma resistência infinita ao conjunto dos fatos consumados que tecem a trama do insuportável. Uma resistência que não se intimida diante de eclosões violentas, mas que sabe distinguir as bifurcações relevantes ou os momentos decisivos dessas supostas "lutas finais", que nos aliviaram, de uma vez por todas, do fardo da divisão. Não se trata aqui, pois, de advogar uma improvável política foucaultiana, mas, sobretudo, de tentar mostrar como uma crítica geral da política contemporânea pode tirar proveito da perspectiva foucaultiana - aquela que ganhou corpo, a partir da "terceira tópica" de sua obra, onde se manifesta distintamente um interesse explícito e intensivo pelas questões políticas (Vigiar e punir, A vontade de saber...).

A primeira das "incitações" foucaultianas para repensar a política se agencia em torno do conceito de plebe. Este vai se apresentar como o primeiro dos operadores da retomada do entendimento político em um contexto no qual a crítica radical da antipolítica estatal (a gestão pastoral do rebanho humano) já não é capaz de se efetuar sob as condições de uma teoria da revolução do tipo marxista. Lembremos brevemente as premissas de uma abordagem

2 Association pour la Taxation des Transactions pour l'Action Citoyenne (Associação pela Tributação das Transações Financeiras para Ajuda aos Cidadãos) [N.T.]. 
foucaultiana da plebe: trata-se de um ponto de vista resolutamente antissociológico, de identificar esse algo que

no corpo social, nas classes, nos grupos, nos próprios indivíduos, que escapa, de uma certa maneira, às relações de poder; alguma coisa que não é a matéria primeira mais ou menos dócil ou recalcitrante, mas que é o movimento centrífugo, a energia inversa, a escapada. 'A' plebe, sem dúvida, não existe, mas 'há plebe'. ${ }^{4}$

Essas observações só fazem sentido se as referirmos ao trabalho de Foucault sobre a noção de poder, ao seu esforço para redefiní-la, abordando-a mais em termos de difusão, de estruturas reticulares, de trocas, de circulações, de máquinas e dispositivos do que em termos de apropriação, de formas separadas e concentradas (a questão do poder reduzida àquela do Estado). "Há plebe", há efeitos de plebe, poderíamos dizer, quando se produzem movimentos de abandono, de resistência, de fuga ou de confronto, em resposta a "todo avanço do poder"; quando se desenham essas brechas ou essas linhas de fuga que suspendem as lógicas do poder, que perturbam ou suspendem a eficácia das "redes de poder". Há esse elemento de irredutibilidade aos jogos de poder, do qual a plebe é, se preferirmos, o elemento dêitico, quando prisioneiros se revoltam, quando - para utilizar o exemplo de Foucault milhares de argelinos saem às ruas de Paris, em 17 de outubro de 1961, para protestar contra o toque de recolher imposto a eles, e são objeto de uma violenta repressão pela polícia parisiense. Assim definida, essa plebe, desprovida de qualquer substância própria, histórica ou social, se apresenta como "o inverso" ou "o limite" em relação ao poder. Não se pode, portanto, atribuir a ela o lugar de um sujeito histórico, cuja ação contínua deixaria sua marca no curso das coisas. Ela surge por fluxos irregulares e variáveis, produzindo, de acordo com as circunstâncias, diversos efeitos de interrupção, deslocamento e fulminação. Seus rostos, assim como suas manifestações, são infinitamente variáveis. Por fim, o que sempre importará, em primeiro lugar, é a constância com que ela será designada como o refugo, o inclassificável, o indescritível ou o infame segundo as lógicas da ordem. Foi o que Foucault apontou, em 1972, sobre o já mencionado protesto argelino:

\begin{abstract}
Ninguém mais - ou quase - fala da manifestação dos argelinos, de 17 de outubro de 1961. Nesse dia, e nos que se seguiram, policiais mataram nas ruas e jogaram no Sena, a fim de afogá-los, aproximadamente 200 argelinos. Em contrapartida, fala-se sempre dos nove mortos de Charonne onde, em 8 de fevereiro de 1962, encerrou-se uma manifestação contra a O.A.S. ${ }^{5}{ }^{6}$
\end{abstract}

\footnotetext{
${ }^{3}$ FOUCAULT, "Poderes e estratégias (entrevista com Jacques Rancière)". In: Ditos e escritos IV : estratégia, podersaber, pp. 244-245 [Tradução modificada].

4 Apesar de Alain Brossat afirmar que se trata de uma citação do texto "Enquête sur les prisons: brisons les barreaux du silence", o texto correto é o supracitado [N.T.].

${ }^{5}$ FOUCAULT, "Inquirição sobre as Prisões: Quebremos a Barreira do Silêncio". In: Ditos e escritos IV : estratégia, poder-saber, p. 12 [Tradução modificada].

${ }^{6}$ A Organisation Armée Secrète ou OAS era uma organização paramilitar clandestina francesa que se opunha à independência da Argélia. [N.T.]
} 
Foucault, aqui, nos chama a atenção para a radical oposição estabelecida, nas sociedades modernas, entre uma noção política do povo e a condição, igualmente política, da plebe. O povo é uma substância política e histórica, pois ele tem acesso à narrativa e à história, ele é a própria inscrição. Comemorações, manifestações, livros, artigos e placas de mármore delimitam a narrativa, não interrompida, desde fevereiro de 1962, sobre o crime policial de Charonne; eles perpetuam a memória das vítimas, na medida em que encaram um povo nesse caso, comunista e anticolonialista. Por trás desses nove mortos, figura-se todo um povo visível e dizível, estruturado pelas suas organizações, representado pelos seus dirigentes sindicais ou políticos, mas também pelos seus mártires e heróis de ontem e de outros tempos ${ }^{7}$.

Em contrapartida, a "massa" indistinta e anônima, sobre a qual disparou a polícia naquela noite de outubro de 1961, não teve seus traços inscritos. Ela é, nesse sentido preciso, uma 'plebe', não essencialmente por ser um grupo-vítima, mas pelo fato de que aquilo que fez e que sofreu, naquela ocasião, estar condenado a uma condição de desaparecimento. Ainda nos dias de hoje, os nomes das vítimas não aparecem em nenhum monumento, o número das vítimas permanece objeto de disputa, os arquivos policiais sobre o acontecimento são pouco acessíveis, as testemunhas, raras; os corpos das vítimas foram, de modo geral, escamoteados, assim como desapareceram seções inteiras de arquivos da brigada fluvial que os havia resgatado... ${ }^{8} \mathrm{O}$ contraste é, portanto, total, entre a capacidade imediata de um reagrupamento plebeu de se formar, de manifestar uma energia que resiste à violência de um poder (o toque de recolher discriminatório imposto aos argelinos), de produzir um efeito potente de interrupção das lógicas da ordem (os argelinos das favelas dos subúrbios convergem em direção a Paris, desafiando as medidas policiais, não cedendo à intimação) e essa espécie de queda de seu acontecimento para fora dos anais, cujo efeito, mesmo quatro décadas mais tarde, ainda não foi compensado. A plebe, nesse sentido, está ligada ao acontecimento, quando manifesta, notadamente, essa capacidade de interromper e desfazer as lógicas policiais, seja de maneira calma e desarmada, como no 17 de outubro de 1961, ou, ao contrário, de modo sedicioso, armado, furioso, incendiário ou com barricadas, como ocorria frequentemente nas emoções populares do século XVIII ou nos motins do século XIX. É apenas na condição de uma teleologia retrospectiva que o 14 de julho de 1789 se transfigura no primeiro passo de um povo revolucionário que se pôs em movimento; em sua eficácia imediata, ele não passa de uma violenta desordem plebeia, com suas figuras familiares de domésticas e artesãos "enfurecidos"; mas é apenas quando esse acontecimento plebeu se encadeia em uma sucessão interrompida de outros (a noite do 04 de agosto etc.) que ele sofre essa gloriosa metamorfose que lhe permite adquirir o sublime estatuto histórico de momento inaugural de uma Revolução e, conjuntamente, de festa nacional de um povo-nação (de um Estado). Por mais que um acontecimento se apresente como pura interrupção do curso do tempo, que ele seja sem precedentes, pura insurreição, é com a plebe, mais do que com o povo, que com ele mantém suas afinidades.

\footnotetext{
${ }^{7}$ Não abordo aqui a questão do notório enfraquecimento dessa narrativa ao longo das últimas décadas. Trato aqui de um regime de narrativa, indexado pela relação entre um grupo constituído, sua experiência coletiva, sua memória e os traços de durabilidade de sua existência.

${ }^{8} \mathrm{Na}$ ocasião do quadragésimo aniversário da manifestação de 17 de outubro de 1961, uma placa comemorativa foi inaugurada sobre a Ponte Saint-Michel, por iniciativa da Prefeitura de Paris, com a solicitação de numerosas associações. Porém, o texto que foi escrito era vago, aludia notadamente a responsabilidade à polícia parisiense e à autoridade política por perpetrar esse crime de Estado.
} 
O povo é acorrentado às suas memórias, às suas tradições, às suas "conquistas" e status, às suas organizações, às suas redes de interdependência com o Estado etc. A plebe, por ser sem substância própria, é filha da ocasião, ela se associa tendo em vista acabar com uma situação, um abuso, um escândalo que suscite seu furor, abater um inimigo execrável; ela se desfaz e se recompõe, sempre de modo variável, no fluxo das lutas e das resistências, materializando afetos e movimentos de subjetivação intrincados às ações. A energia popular é capturada por organizações - partidos e sindicatos, associações - cuja função é dissociar povo e acontecimento. A plebe é uma força que se compõe contra lógicas de poder opressivas, policiais, e que produz movimentos de desintimação ${ }^{9}$ tão vivos, que se desvela no instante a inconsistência, a obsolescência ou a infâmia da situação estabelecida.

Há, em Foucault, o que poderíamos chamar de um círculo da plebe. De certa maneira, a plebe pode ser designada como uma produção da ordem, uma invenção da polícia dos poderes modernos. A instituição penitenciária, por exemplo, é a manufatura de uma "espécie" específica, os irrecuperáveis, hoje em dia, dos "prisioneiros de risco", e a presença desse "dejeto" da ordem social vai servir de justificativa aos dispositivos de controle e repressão. Se não houvesse essa constância do crime, dos ilegalismos, da insegurança, das incivilidades, que é o fato mesmo da plebe, não existiria a necessidade da polícia:

Se aceitamos no meio de nós esses homens de uniforme, que têm o direito exclusivo de portar armas, de exigir nossos documentos (...) - como isso seria possível se não houvesse criminosos? E se não houvesse todos os dias nos jornais esses artigos que nos relatam o quão numerosos e perigosos são esses criminosos? ${ }^{\text {10 }}$

De outro lado, sublinha Foucault, a plebe ocupa, na sociedade capitalista, um lugar estratégico, já que ela permite aos dominantes reativar sem cessar um corte no interior do povo ou do proletariado, dividindo o povo contra si mesmo. Essa divisão visa a enfraquecer a energia popular, uma vez que ela está virtualmente direcionada contra a ordem, a dominação, a polícia. "No fundo, insiste Foucault, o que causa medo ao capitalismo, com ou sem razão, desde 1789, desde 1849 e 1870, é a sedição, a revolta: os que saem nas ruas com suas facas e fuzis dispostos à ação direta e violenta"11. A divisão produzida sem cessar por um certo número de operações policiais (aquela, por exemplo, que consiste em opor o "trabalhador honesto" ao ladrão ou ao delinquente ou ainda, hoje em dia, em opor o trabalhador regular ao "clandestino" que trabalha na ilegalidade) entre povo (ou proletariado) e plebe ou malandro ${ }^{12}$; tem por finalidade produzir associações pejorativas entre plebe e

\footnotetext{
${ }^{9}$ Em francês o autor utiliza a palavra "désassignation", que poderia ser traduzida, de acordo com o neologismo, por "desatribuição" ou "desdesignação"; contudo, visando conservar o sentido jurídico-policial em questão, escolhemos "desintimação" [N. T.].

${ }^{10}$ FOUCAULT, "Entrevista sobre a prisão: o Livro e o Método”. In: Ditos e escritos IV: estratégia, poder-saber, p. 168 [Tradução modificada].

${ }^{11}$ FOUCAULT, “Table Ronde”. In: Dits et Écrits II: 1970-1975, p. 334. [Tradução para o português realizada por nós].

12 Em francês o autor utiliza a palavra "pègre", que poderia ser traduzida de diferentes maneiras para o português. Escolhemos "malandro", pois a palavra corresponde melhor às ambivalências morais atribuídas à classe trabalhadora no interior da sociedade brasileira [N. T.].
} 
violência, e conduzir o povo "são" a adotar o ponto de vista da ordem sobre todos os fenômenos de violência, notadamente de violência política, amotinadora ou sediciosa.

Não é o longo discurso, a longa paciência da estratégia revolucionária e dos amanhãs que cantam - sempre adiados para o depois de amanhã - que assustam a burguesia; é a capacidade atual da plebe de entrar em efervescência hoje, amanhã, e de produzir, assim, essa "fuga" para fora das relações de poder, que abre esses "outros lugares", esses "modos alternativos" da política e da vida em comum, que as pessoas do Estado associam à "anarquia" (que eles concebem ridiculamente como equivalente ao caos). A burguesia tem medo é da imprevisibilidade das sublevações e do fluxo das insurreições plebeias, de todas essas irregularidades e transbordamentos que minam a disciplina, a produção, as circulações controladas, etc. E, portanto, a classe dominante se esforçará para suscitar, entre o proletariado revolucionário, uma constante aversão em relação aos movimentos plebeus, dizendo-lhe: "Com essa gente que está pronta para ser a ponta de lança de suas sedições, não é possível, para o benefício de seu próprio interesse, que você faça aliança com ela"13. Legalização da classe operária, institucionalização do movimento operário contra a marginalização e estigmatização constante da plebe como intrinsecamente violenta:

Toda essa população móvel, [...] constantemente disposta a ir à rua, a provocar motim; essa gente foi de certo modo transformada em exemplo negativo pelo sistema penal. E toda a desvalorização jurídica e moral que se fez da violência, do roubo etc., toda essa educação moral que o professor proporcionava em termos positivos ao proletariado, a justiça o faz em termos negativos. $E$ assim foi que a divisão entre o proletariado e o mundo não proletarizado não cessou de ser reproduzida e reintroduzida, pois pensava-se que o contato entre um e outro era um perigoso fermento do motim. ${ }^{14}$

A perspectiva foucaultiana não é, aqui, apenas analítica ou constatativa; o ponto de vista que ela adota sobre essa divisão é aquele de uma deserção das relações de poder, de uma resistência às lógicas e "armadilhas" da dominação e da ordem. É claro que, deste ângulo, o proletariado é o lado trapaceado dessa operação que o separa da plebe. O reformismo e o contrato implícito que o funda (a "respeitabilidade" do proletariado lhe é assentada ao preço de depositar sua reserva de violência) é o túmulo de suas esperanças (aqui, Foucault restabelece sua inspiração soreliana). A questão estratégica será, por conseguinte, a de saber como a potência (potentia) proletária pode se religar à energia e à iniciativa plebeia, ao invés de lhe virar as costas.

Quando eu dizia que o problema consistia precisamente em mostrar ao proletariado que o sistema de justiça que lhe é proposto, que lhe é imposto, é, na realidade, um instrumento de poder, isso era precisamente para que a aliança com a plebe não fosse simplesmente uma aliança tática, de um dia ou de uma noite, mas para que efetivamente possa existir, entre um proletariado

${ }^{13}$ FOUCAULT, “Table Ronde”. In: Dits et Écrits II: 1970-1975, p. 334.

${ }^{14}$ FOUCAULT, “Table Ronde”. In: Dits et Écrits II: 1970-1975, p. 334. 
que não tem absolutamente a ideologia da plebe, e uma plebe que não tem absolutamente as práticas sociais do proletariado, outra coisa que um encontro conjuntural. ${ }^{15}$

A “aliança” que Foucault, aqui, se esforça a pensar não é equivalente àquela de um partido parlamentar com outro, de uma classe com outra - tática ou estratégica, em vista de um objetivo comum. Não se trata tanto de selar os acordos do motim ou da revolução quanto de considerar o movimento global de uma migração da massa popular, proletária, para fora das densas redes do poder que a fazem cativas do Estado e de seu discurso. Trata-se de se deslocar em direção a essa margem, a esse "limite" ou a esse ponto de fuga das relações de poder existentes, tal como se produzem os massivos movimentos de deserção, de descentramento $e$ de irreconciliação em relação àquilo que, em nossas sociedades, é constitutivo da polícia das condutas e dos discursos e, nesse sentido, fator do desastre sem fim que é o presente (Benjamin):

Gostaria de lançar uma pergunta: e se fosse a própria massa que se marginaliza? Ou seja, e se fosse justamente o proletariado e os jovens proletários que recusam a ideologia do proletariado? Ao mesmo tempo que a massa se massifica, é bem possível que a massa se marginaliza; contrariamente ao que poderíamos acreditar, entre as pessoas que vão aos tribunais, não há tantos desempregados. São jovens operários que dizem a si mesmos: por que passar toda a minha vida suando por cem mil francos ao mês ao passo que...É a partir desse momento que a massa começa a se marginalizar ${ }^{16}$.

É evidente que isto que Foucault enuncia aqui não tem valor de programa (para uma política ou uma filosofia política), mas, sim, de estímulo para se estabelecerem novas disposições a partir das quais poderia ser pensada uma política radical. O que Foucault sugere, notadamente, é que a política seja pensada menos em termos de armazenamento de forças, de acumulação, de conquista, e mais como capacidade de desprendimento, de deserção, de desvinculação, de decomposição, de demolição, mas também de deslocamento em direção a essas "bordas" onde as relações de poder encontram seu limite. Foucault, evidentemente, é aquele que está mais consciente do fato de que não existe posição de pura e simples exterioridade às relações de poder: lá onde se compõe uma força que resiste a uma outra força estabelecem-se novas relações e materializações de poder - é o paradigma dessas organizações revolucionárias que se tornam formidáveis máquinas de reciclagem dos modelos autoritários; porém, aquilo que faz de uma organização, como o Grupo de Informações sobre as Prisões (G.I.P.), nesse sentido, algo exemplar, é a vontade de deslocar a ação política para o lado de uma óptica plebeia, superando, assim, as armadilhas da sua inscrição nos formatos já estabelecidos, a partir dos quais se restabelecem as relações tradicionais de poder. O G.I.P. se constitui como um lugar de encontros, de debates e de iniciativas fundadas, primeiramente, pela recusa às tutelas políticas (das organizações de

${ }^{15}$ FOUCAULT, “Table Ronde”. In: Dits et Écrits II: 1970-1975, p. 336, grifos meus.

${ }^{16}$ FOUCAULT, “Table Ronde”. In: Dits et Écrits II: 1970-1975, p. 338. 
extrema esquerda), culturais (dos intelectuais), mas também de escolhas que reconduziriam à fatal cisão entre povo e plebe. Como efeito direto do grande movimento de maio de 1968, o G.I.P. poderia ter sido concebido como grupo destinado a auxiliar os militantes encarcerados, reclamando para eles um status político, separando sua condição (honrável) daquela dos presos comuns. Essa abordagem da instituição penitenciária estaria situada, por exemplo, na mesma linha que os comunistas adotaram durante a Segunda Guerra Mundial, recusando com indignação a propaganda da ocupação e dos colaboradores, que fazia da resistência "bandidos" ou "terroristas" - isto é, plebe (e, nesse sentido, exterminável). Ao contrário, ao insistir que o problema que preocupa o G.I.P. não é o do "regime político nas prisões, mas aquele do regime das prisões", Foucault recusa a divisão entre povo e plebe todos os presos, de todas as condições, e seus familiares, estão incluídos nas preocupações do G.I.P. Esse deslocamento de "ponto de vista", desde onde se determina uma ação política, está naturalmente sujeito à incompreensão de todos esses "progressistas", que incluíram a divisão entre o povo (proletariado) e plebe em seus programas (tanto no sentido informativo quanto político do termo) - o P.C., a C.G.T. ${ }^{17}$, as organizações do movimento operário tradicional. Essa oposição entre uma política "proletária" e uma política "plebeia" também está situada no plano das formas e dos meios de ações: para Foucault, o G.I.P. apresenta uma outra política possível, recusando as estruturas hierárquicas, os jogos de notoriedade, o mimetismo gregário:

\begin{abstract}
No G.I.P. isso significa: nenhuma organização, nenhum chefe, fazemos verdadeiramente tudo para que ele permaneça um movimento anônimo, que só exista pelas três letras de seu nome. Todo mundo pode falar. Quem quer que fale, não fala porque tem um título ou um nome, mas porque tem algo a dizer. A única palavra de ordem do G.I.P. é: "a palavra aos detentos!"18
\end{abstract}

Essa é a característica mesma da plebe, informal, protoplasmática, nômade, que se transpõe para o campo demarcado da ação. Quando perguntam a Foucault até que ponto o G.I.P. era um grupo, se tinha uma "constituição orgânica", ele responde claramente: "Não, nenhuma. Era um espaço de reunião. O grupo não estava constituído...”. O acento posto sobre o desejo de anonimato (paradoxal para um agrupamento que agrega algumas celebridades do mundo literário e universitário) vai no mesmo sentido. O traço característico da plebe é apresentar rostos e nomes incertos, intercambiáveis, evanescentes - na contramão do povo formal, rigorosamente identificado com seus chefes, seus heróis e mártires. Na época em que Foucault se esforça para definir os alinhamentos de uma outra política possível, o modelo leninista ainda prosperava na extrema esquerda - aquele de uma unidade política de ferro, indexada por uma organização militar, disciplinar, hierárquica, galvanizada. Trata-se de fazer de uma só vez algo totalmente contrário a esse modelo, tal como impregnava a cultura política radical dos anos 1970, e, também, contrário à política parlamentar (que submete os partidos às condições do Estado e do estatismo), concebendo-se como experiência de

\footnotetext{
${ }^{17}$ P.C. - Partido Comunista Francês. C.G.T. - Confederação Geral do Trabalho (nome da confederação sindical francesa) [N.T.].

${ }^{18}$ FOUCAULT, "O Grande Internamento”. In: Ditos e escritos I: problematização do sujeito: Psicologia, Psiquiatria e Psicanálise, p. 266 [Tradução modificada].
} 
inspiração libertária: antiautoritária ("nada de chefes, nada de ordens dadas"), igualitária ("a palavra à disposição de todos”) e molecular (sem organização).

Uma vez lançadas essas "incitações” por Foucault, o modelo leninista entrou em colapso na extrema esquerda formal, que estava em vias de rápida conversão, mesmo que ainda não declarada, às condições da aparelhagem parlamentar da política. Quem se surpreenderia, então, que as sugestões foucaultianas encontrassem, cada vez mais distintamente, práticas, gestos, atores e, de um modo mais geral, um novo tom da política radical, que tem em comum a recusa desses rituais da política que, todos, nos reconduzem a uma instituição parlamentar e a um significante maior (a democracia), cujo declínio histórico, contudo, sucumbe diante dos olhos de todos e de cada um?

De resto, as questões sobre as quais se cristalizou, de modo crescente, a política viva (extraparlamentar) nos países da Europa ocidental não são precisamente aquelas no coração das quais aparecem atores e desafios plebeus: sem papéis, solicitantes de asilo, desempregados de longa duração, jovens das cidades e dos subúrbios, artistas intermitentes, doentes de AIDS, desamparados, abandonados etc? Por conseguinte, o tabuleiro da batalha que se trava muda completamente: não é mais um fronte de luta única, uma batalha engajada nas bases de metassujeitos (proletariado contra burguesia, "representados" por seus respectivos partidos), na perspectiva do obstáculo final, mas uma multitude de cenas dispersas de enfrentamento, de focos descentralizados, de resistências que faíscam de modo mais ou menos efêmero ou durável. Aqueles que só veem nessas proliferações dispersão e perda de substância, anomia, desaparecimento de toda força suscetível de fazer face à dominação, simplesmente não compreendem que somos arrebatados por uma mudança de época: o que está em jogo não é nada mais do que a passagem de um regime clausewitziano da política (a guerra das classes como parodiando a guerra entre os Estados-nações e culminando em uma grande batalha que decide tudo - mas que nunca chega, ao menos não em nossas latitudes) para um regime de proliferações e de intensidades, no qual a divisão se perpetua e se coloca à prova na forma de uma multitude de enfrentamentos heterogêneos exceto o fato de que todos convergem, não para uma "melhora" do sistema, mas para uma deserção generalizada. O que chama à luta dos sem papéis não é uma "fortaleza Europa", um pouco menos impermeável, ou ministros do interior, um pouco menos inclinados a voos fretados para deportação, mas, sim, um retorno da hospitalidade; um retorno que passe por tantos movimentos de desprendimento, tantos deslocamentos violentos, tantos esquecimentos de nós mesmos, tal como somos moldados por nossa condição imunitária e nossas angústias securitárias, que um dia viríamos "enxergar" Sangatte ${ }^{19}$ e suas zonas de espera com a mesma incredulidade nauseante com que vemos a fogueira das bruxas e os combates de gladiadores. ${ }^{20}$

O círculo da plebe é, portanto, esse retorno inesperado, no seio da renovação das práticas políticas e da intensificação das formas de deserção, aquilo mesmo que o cálculo dos dominantes tinha concebido como uma máquina de guerra contra os desígnios prometeicos

\footnotetext{
${ }^{19}$ Sangatte é uma comuna francesa situada no departamento de Pas-de-Calais e que ganhou notoriedade por sediar, entre os anos de 1999 e 2002, um campo de refugiados que foi palco de uma série de revoltas que ocorreram entre os anos de 2001 e 2002, quando, inclusive sob pressão externa, Nicolas Sarkozy, então ministro do Interior, se vê forçado a fechar e dar fim ao campo [N.T.].

${ }^{20}$ Cf. a esse respeito o dossiê consagrado às zonas de espera, lançado pela revista Drôle d'Époque, número 13, Nancy, novembre 2003.
} 
do proletariado (mesmo contra a energia simples do povo de Michelet e Péguy). A plebe retorna como agente de dissolução, elemento de irregularidade, mas também como vetor de deslocamentos e de invenção (o capitalismo não sendo aquilo que deveríamos destruir e superar, mas, sim, desertar e esquecer, aprendendo a "fazer diferentemente", dando o "passo atrás decisivo", despossuindo-nos, segundo a bela lição de Paul Veyne sobre a passagem das modalidades de vida antigas à vida cristã).

Os movimentos plebeus, os modos plebeus de ação política não se articulam segundo um regime dialético do qual eles assumiriam a superação, conservando-o, precisamente, (uma tradução possível da famosa Aufhebung, mãe de todas as dialéticas), mas colocando as diferenças, diz Foucault. O modo de abordagem plebeu da política é indissociável desse movimento de abandono massivo dos esquemas hegelianos ("não ser mais de modo algum hegeliano" palavra de ordem foucaultiana). O deslocamento ou o rompimento violento a que essa abordagem convida passa pela provação formidável e dolorosa da deserção diante de toda uma série de significantes importantes da política contemporânea - o homem do discurso humanista e humanitário, é claro, mas também o cidadão do discurso da pós-democracia consensual, humanitária, "legalista" - que acabou confirmando que era apenas o pseudônimo do homem da classe média das metrópoles do "primeiro mundo". A plebe volta com força, de uma forma nada idílica (Bin Laden e os seus têm traços de uma variedade de plebe furiosa, ubíqua e globalizada) sobre as ruínas dessa versão (agora obesa e despótica) de esperança democrática, que apostou tudo na instituição republicana, no sufrágio universal, na competição dos partidos estatais, no sistema parlamentar e no poder da imprensa (geralmente confundida com a decorativa "liberdade de opinião").

Esses são os acasos improváveis, os brilhos de violência imprevisíveis que lembram ao mundo a permanência dessa poeira humana condenada ao esquecimento e às trevas, que é a plebe. Esses são os extratos dos arquivos do Hospital Geral e da Bastilha que, contra toda expectativa, salvam alguma coisa da vida ínfima desses "homens infames" dos séculos XVII e XVIII (dementes, depravados, apóstatas religiosos, mulheres da rua...), dessas existências obscuras cercadas um dia pelo feixe luminoso do poder; são essas cartas de combatentes mortos no fronte que, décadas mais tarde, reemergem ao acaso em um aniversário, em uma comemoração; é a memória redigida na prisão pelo parricida Pierre Rivière, são as cartas e os diários dispersos de Richard Durn, o "assassino louco" de Nanterre, do qual a imprensa distribui os fragmentos... ${ }^{21}$. Esses resgates são apenas recifes isolados no meio do oceano de esquecimento, onde se imerge a totalidade infinita dos acontecimentos plebeus. Mas eles são em número suficiente para atestar a afinidade constitutiva entre a plebe e o acontecimento quando este não é um desastre puro e simples (e novamente: Auschwitz e Hiroshima são operações tanatocráticas, cujo propósito é reduzir à condição de plebe - exterminável - uma fração da humanidade). O que a obra de Foucault mostra é o quanto somos constantemente atravessados, com relutância, por uma multitude de acontecimentos plebeus - ali onde somos frequentemente levados a buscar a História ou a "narrá-la" ao lado dos "cumes", do que inscreve traços visíveis, gloriosos ou desastrosos, disso que constitui um patrimônio, do que atesta um deslocamento:

21 A esse respeito, ver: FARGE; FOUCAULT, Le Désordre des familles, lettres de cachet des archives de la Bastille; FOUCAULT, Eu, Pierre Rivière, que degolei minha mãe, minha irmã e meu irmão; FOUCAULT, "A vida dos homens infames". In: Ditos e escritos IV : estratégia, poder-saber, p. 203-222. Sobre a "tuerie de Nanterre", tomo a liberdade de me referir ao meu artigo sobre Durn em Le Passant ordinaire, n. 40/41. 
Nosso inconsciente [histórico] é feito desses milhões, desses bilhões de pequenos acontecimentos que, pouco a pouco, como gotas de chuva, erodem nosso corpo, nosso modo de pensar, e depois o acaso faz com que um desses microacontecimentos deixe traços e possa se tornar uma espécie de monumento, um livro, um filme ${ }^{22}$.

Definindo-se como um homem "amante da poeira", expressando a ambição de escrever "histórias" da "poeira", Foucault nos encoraja a recondicionar nossa percepção do acontecimento ao lado do infinitesimal, do inominável, do indizível; a tentar entender com que razão - mas definitivamente - o "golpe de loucura" de Richard Durn fez mais acontecimento e história do que uma dúzia de remodelações ministeriais; a ver em Pierre Rivière menos um lunático infeliz do que a testemunha de uma história massacrante marcada pelas guerras napoleônicas, pelas conquistas coloniais, pelas violências sociais...

O que caracteriza propriamente a ação da plebe, tal gesto plebeu estridente e isolado ou, ao contrário, tal movimento ou passagem ao ato coletivo, é sua capacidade de marcar o presente, de desfigurá-lo - que é outra forma de torná-lo sensível, por um instante e, raramente, de forma permanente, à deformidade intolerável... É o caso do "gesto" de Pierre Rivière, que dilacera a ordem das famílias; daquele de Richard Durn, que retalha a instituição política; daquele de Bin Laden, que corta a ordem (imperial) mundial. O acontecimento está aí, onde o escândalo de um gesto (como um grito) plebeu cria uma nova e insuportável visibilidade. O efeito de choque produzido por tais atos desligados de toda "lógica" dos encadeamentos e dos discursos depende do que emana dos invisíveis, dos impotentes ou dos vencidos. Ele depende da sua desvinculação dos atos de linguagem ou dos esforços de comunicação. Há essa afinidade inalterável da plebe com o silêncio, o déficit da fala, a impossibilidade de "encadear" em uma frase (Lyotard) o grito ou a voz, lá onde o discurso está ausente. Foucault:

Sim, eu bem que gostaria de escrever a história dos vencidos. É um belo sonho partilhado por muitos: por fim, dar a palavra aos que não puderam tomá-la até os dias de hoje, aos que foram obrigados ao silêncio pela história, pela violência da história, por todos os sistemas de dominação e de exploração. $^{23}$

O que testemunham muitos acontecimentos plebeus de hoje, não-vistos ou, ao contrário, destacados como o próprio inominável (Durn), é o colapso do "sonho" foucaultiano aqui enunciado: nosso tempo é, com efeito, aquele no qual "muitos compartilham" sobretudo o desejo de enterrar a história dos vencidos sob uma densa capa de silêncio e impedir, mais do que nunca, que os vencidos tenham acesso à palavra. A televisão, entre outros, é esse dispositivo de poder (de monopólio da “comunicação”), cuja finalidade primeira é impedir todo tipo de tomada de palavra plebeia - daí a importância e a

22 FOUCAULT, “O retorno de Pierre Rivière”. In: Ditos e Escritos VII: Arte, Epistemologia, Filosofia e História da Medicina, pp. 82-83 [Citação e tradução modificadas].

${ }^{23}$ FOUCAULT, “A tortura é a razão". In: Ditos e Escritos VIII: Segurança, Penalidade e Prisão, p. 104. 
legitimidade das irrupções intermitentes do espetáculo nos programas de variedade e nos jornais televisivos.

Contudo, por outro lado, diremos que é justamente por não ter uma linguagem própria e por experimentar esse déficit constante do lado da linguagem que a plebe está ligada ao acontecimento. Os mestres da língua (políticos, clérigos, jornalistas, padres ...) há muito abandonaram essa configuração na qual o discurso (do orador, do panfletário, do pregador ...) conecta-se à ação transformadora. Sua aptidão para o discurso está ligada ao estado de coisas, suspensivo do acontecimento, policial - ela se quer exorcismo de toda violência, seja qual for. Ora, o acontecimento faz violência, mortalmente, às coisas estabelecidas, à ordem das posições, às regularidades e às rotinas eficazes. O que os instruídos e os governantes comumente detectam e designam como o índice de "barbárie" dos movimentos ou gestos plebeus refere-se sempre, de uma forma ou de outra, a essa impossibilidade de incluí-los nessas redes linguageiras e comunicacionais que são os dispositivos mais eficientes de neutralização das intensidades violentas. A plebe lacônica ou muda que não se comunica, que não delibera, mas passa ao ato (o Onze de Setembro) - eis o que mantém intacta a marca apavorante e aterrorizante do insuportável.

Em outras palavras, diremos: na boca de políticos, professores, pessoas da televisão e padres (etc.), a linguagem é o que tem como objetivo principal impedir as pessoas de sublevarem-se. Ora, toda política orientada para a emancipação começa não com uma divina surpresa eleitoral, mas, sim, com uma sublevação. É o que lembra Foucault em sua série de artigos tão condenados - justamente por essa e outras razões - sobre o levante iraniano que, no final da década de 1970, provocou a queda do Xá:

Eu não concordo com aquele que dissesse: "Inútil se insurgir, sempre será a mesma coisa". Não se impõe a lei a quem arrisca sua vida diante de um poder. Há ou não motivo para se revoltar? Deixemos aberta a questão. Insurge-se, é um fato; é por isso que a subjetividade (não a dos grandes homens, mas a de qualquer um) se introduz na história e lhe dá seu alento. Um delinquente arrisca sua vida contra castigos abusivos; um louco não suporta mais estar preso e decaído; um povo recusa o regime que o oprime. Isso não torna o primeiro inocente, não cura o outro, e não garante ao terceiro os amanhãs prometidos. (...) Ninguém é obrigado a achar que aquelas vozes confusas cantam melhor do que as outras e falam da essência do verdadeiro. Basta que elas existam e que tenham contra elas tudo o que se obstina em fazê-las calar, para que faça sentido escutá-las e buscar o que elas querem dizer. Questão de moral? Talvez. ${ }^{24}$

A plebe é o "qualquer um" que manifesta uma capacidade preservada de se sublevar; uma aptidão a produzir efeitos que prevalecem sobre o "falar claro" ou o "dizer verdadeiro", aos quais as nossas sociedades concedem todos os privilégios. Na sua própria "confusão", as vozes e os gritos que acompanham o levante são dotados de uma forte capacidade de enunciação: apelam ao imemorial, ao insuprimível - à irredutibilidade do "resto" plebeu às

${ }^{24}$ FOUCAULT, "É inútil revoltar-se?”. In: Ditos e Escritos V: Ética, Sexualidade, Política, p. 80 [tradução modificada]. 
disciplinas e aos regulamentos policiais. Elas nos lembram que mesmo aquilo que está condenado a um rigoroso regime de desaparecimento - a vida e a energia da plebe - retorna sem cessar, e isso mesmo é o que torna a história não apenas uma pura forma vazia, um puro continuum sem conteúdo:

O movimento com que um só homem, um grupo, uma minoria ou todo um povo diz: 'Não obedeço mais', e joga na cara de um poder que ele considera injusto o risco de sua vida - esse movimento me parece irredutível. Porque nenhum poder é capaz de torná-lo absolutamente impossível (...). Todas as desilusões da história de nada valem: é por existirem tais vozes que o tempo dos homens não tem a forma da evolução, mas justamente a da 'história'. ${ }^{25}$

A história é - mas não o sabemos desde Nietzsche, pelo menos, e Blanqui? - essa combinação do retorno do imemorial (o mesmo) e do surgimento do heterogêneo. Desse duplo regime, a plebe é a encarnação exata: esse "sempre aí" recoberto pelos estratos do desprezo e do esquecimento; esse "sempre novo" que se inventa ao longo das sequências e dos acontecimentos sob nova roupagem, em novos gestos. Os mulás pregando a insubmissão, de mesquita em mesquita, durante o levante iraniano, é o retorno de Münster, de Savonarola, a vingança dos vencidos, entendida não como ressentimento, mas como o afeto que põe em movimento a pura energia resistente ao poder, desmascarando-o. Mas é, igualmente, o inédito e o sem precedente de uma situação inconcebível aos olhos de todos aqueles especialistas que diagnosticaram a irreversível "ocidentalização" da sociedade iraniana...

A plebe, portanto, está ligada à história (o retorno do desaparecido e a produção das diferenças), na medida em que ela é essa contraforça que impede o poder, dispersa-o, embaralha seus efeitos - na medida, pode-se dizer, em que ela é o im-poder. O poder, com efeito, longe de coincidir com a composição de uma história, é o que visa a impedi-la. $\mathrm{O}$ próprio de uma máquina de poder é constituir o homogêneo, regularidades, é combater o imprevisto, densificar, identificar. E o próprio do poder é repelir todo limite. As lógicas do poder são, por definição, antipolíticas, porque são estritamente alérgicas aos intervalos e a um regime de diversidade e divisão. A plebe é, justamente, o que resiste ao poder lá onde ele é, "por seus mecanismos", levado ao infinito, diz Foucault. A plebe é, portanto, o que traz a política de volta ao jogo do poder, dificultando-o. Ela encarna ou dá corpo a essa espécie de direito natural de resistência à expansão mecânica do poder, resistência sem a qual nossas sociedades são apenas policiais (o que não significa, exclusivamente, repressivas). Um direito natural, como tal, não pode ser codificado; ele se proclama, ele se constata. A plebe permanece infinitamente sem "legitimidade", sendo apenas o corpo ou a textura desse jogo infinito de forças antagônicas do qual é feita a "vida" e cuja lei é: onde se instaura o poder, surge uma força que resiste e se opõe a ele. A passagem - condicional - à dimensão moral se dará na afirmação de uma inevitabilidade da resistência da plebe à infinitude do poder, custe o que custar, seja qual for a forma que assuma, para além do bem e do mal (o Onze de Setembro, precisamente). Se houvesse uma pequena música utópica que acompanhasse essa fenomenologia da plebe, com suas centenas de faces e ações, ela se agarraria a esta definição:

${ }^{25}$ FOUCAULT, “É inútil revoltar-se?”. In: Ditos e Escritos V: Ética, Sexualidade, Política, pp. 77 e 80. 
é aquela que, obstinadamente e sem fim, apresenta o limite de todo poder e objeta a sua interminável expansão.

Uma outra maneira de dizer, que aproximaria Foucault a Pierre Clastres, seria: o poder é aquilo que não é evidente. A figura do abuso de poder se insere em qualquer forma, ainda que legítima, de institucionalização do poder. Daí a importância de se pensar o fora do campo (fora do poder) radical desse "direito" que funda esses movimentos que resistem ao poder ou o contaminam, mas que, também, simultaneamente, reativam a própria política. $\mathrm{O}$ que Foucault nomeia: "ser respeitoso quando uma singularidade se insurge, intransigente quando o poder infringe o universal" 26 , o "logo que" diz suficientemente: não há poder que o filósofo possa decretar substancialmente bom a ponto de se unir a ele. Aqui, Foucault separa-se distintamente de seus amigos maoístas da época, rejeitando, indiscriminadamente, a figura autoritária do dirigente onisciente, a do tribunal "popular" e a do intelectual fiel ${ }^{27}$. Sob o fogo de sua crítica, a logomaquia maoísta é revelada como mais um avatar da política reduzida às condições do Estado. Buscando traçar os contornos de uma política deslocada para o lado da plebe, Foucault renova o pensamento libertário da ação.

\section{Referências bibliográficas}

BROSSAT, Alain; LEFEUVRE-DÉOTTE, Martine et LAACHER, Smaïn. "Dossier: Les zones d'attente. Après Sangatte. Nouvelles migrations, nouveaux enjeux de Smaïn Laacher (La Dispute)". In: Drôle d'époque, n. 13, 29 janvier 2008.

BROSSAT, Alain. "De Pierre Rivière à Richard Durn: folie furieuse et veridiction". In: Passant ordinaire (Bègles), n. 40/41, mai 2002 - septembre 2002. Disponível em: http://www.passant-ordinaire.org/revue/40-41-408.asp

FARGE, Arlette; FOUCAULT, Michel: Le Désordre des familles, lettres de cachet des archives de la Bastille. Paris: Archives Gallimard/Julliard, 1982;

FOUCAULT, Michel. “Table Ronde”. In: Dits et Écrits II: 1970-1975. Paris: Gallimard, 1994. Eu, Pierre Rivière, que degolei minha mãe, minha irmã e meu irmão. Rio de Janeiro: Graal, 1977

. "O Grande Internamento". In: Ditos e escritos I: problematização do sujeito: Psicologia, Psiquiatria e Psicanálise. Tradução: Vera Lucia Avellar Ribeiro. Rio de Janeiro: Forense Universitária, 1999.

"Entrevista sobre a prisão: o Livro e o Método". In: Ditos e escritos IV : estratégia, poder-saber. Tradução: Vera Lucia Avellar Ribeiro. Rio de Janeiro: Forense Universitária, 2006.

\footnotetext{
${ }^{26}$ FOUCAULT, "É inútil revoltar-se?". In: Ditos e Escritos V: Ética, Sexualidade, Política, p. 81 [citação modificada].

${ }^{27}$ Ver, por exemplo: FOUCAULT, "Sobre a justiça popular. Debate com os maoístas". In: Ditos e Escritos VI: Repensar a Política, pp. 34-68.
} 
. “Inquirição sobre as Prisões: Quebremos a Barreira do Silêncio”. In: Ditos e escritos IV: estratégia, poder-saber. Tradução: Vera Lucia Avellar Ribeiro. Rio de Janeiro: Forense Universitária, 2006.

"Poderes e estratégias (entrevista com Jacques Rancière)". In: Ditos e escritos IV: estratégia, poder-saber. Tradução: Vera Lucia Avellar Ribeiro. Rio de Janeiro: Forense Universitária, 2006.

"A vida dos homens infames". In: Ditos e escritos IV : estratégia, poder-saber. Tradução: Vera Lucia Avellar Ribeiro. Rio de Janeiro: Forense Universitária, 2006.

"Sobre a justiça popular. Debate com os maoístas". In: Ditos e Escritos VI: Repensar a Política. Rio de Janeiro: Forense Universitária, 2010.

"O retorno de Pierre Rivière". In: Ditos e Escritos VII: Arte, Epistemologia, Filosofia e História da Medicina. Rio de Janeiro: Forense Universitária, 2011.

"A tortura é a razão". In: Ditos e Escritos VIII: Segurança, Penalidade e Prisão. Rio de Janeiro: Forense Universitária, 2012. 